STUDIES IN POPULAR CULTURE
Picturing home

Domestic life and modernity in 1940s British film

HOLLIE PRICE

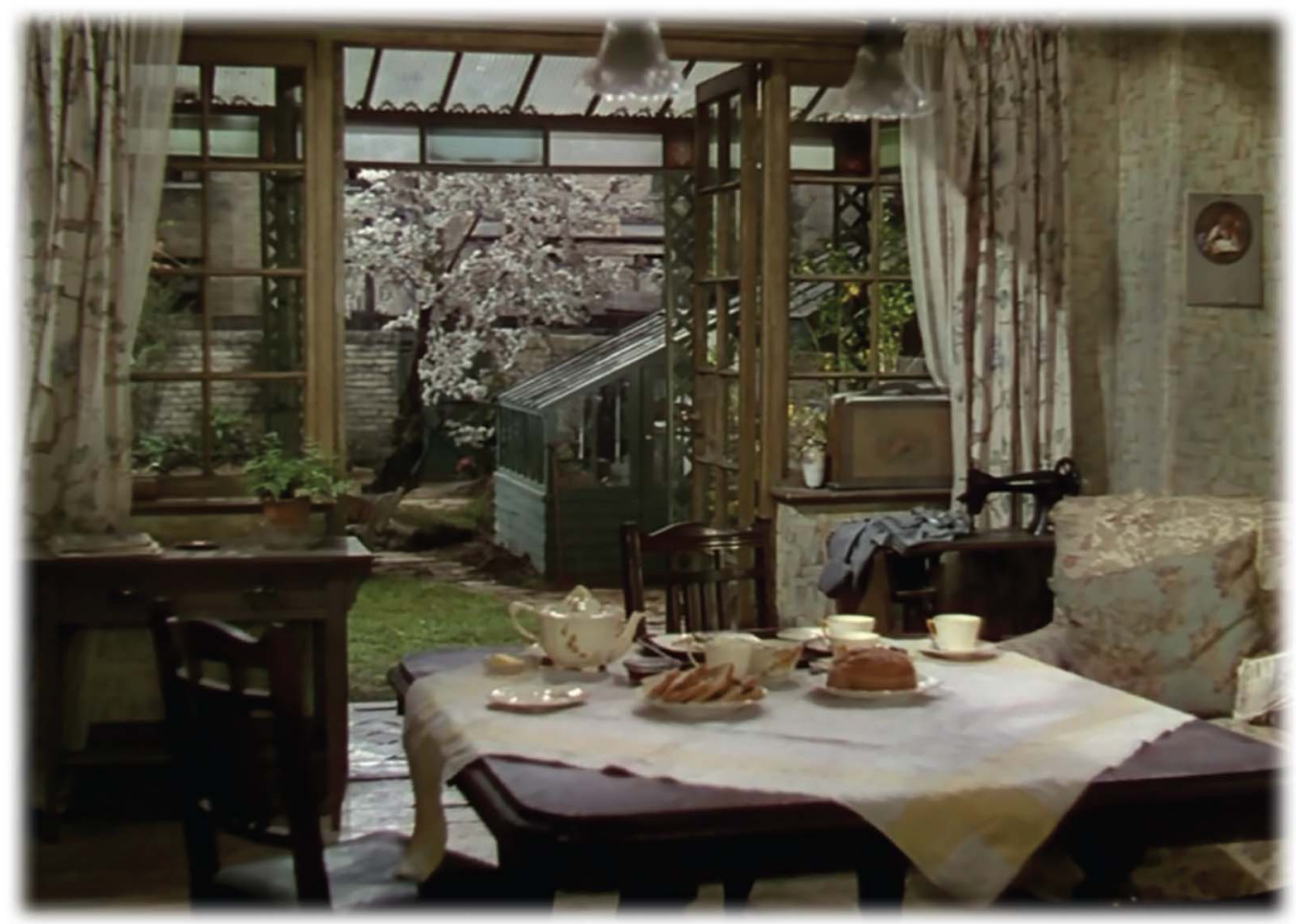




\section{Picturing home}

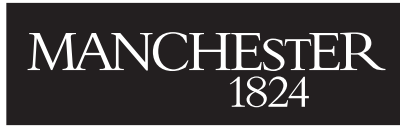

Manchester University Press 


\section{STUDIES IN POPULAR CULTURE}

\section{General editor: Professor Jeffrey Richards}

Already published

Dancing in the English style: consumption, Americanisation, and national identity in Britain,

$$
\text { 1918-50 }
$$$$
\text { Allison Abra }
$$

Christmas in nineteenth-century England

Neil Armstrong

Healthy living in the Alps: the origins of winter tourism in Switzerland, 1860-19/4 Susan Barton

Working-class organisations and popular tourism, 1840-1970

$$
\text { Susan Barton }
$$

Leisure, citizenship and working-class men in Britain, 1850-1945 Brad Beaven

Leisure and cultural conflict in twentieth-century Britain Brett Bebber (ed.)

Leisure cultures in urban Europe, c.|700-1870: a transnational perspective Peter Borsay and Jan Hein Furnée (eds)

British railway enthusiasm

$$
\text { lan Carter }
$$

Railways and culture in Britain

$$
\text { lan Carter }
$$

Time, work and leisure: life changes in England since 1700 Hugh Cunningham

Darts in England, 1900-39: a social history Patrick Chaplin

Holiday camps in twentieth-century Britain: packaging pleasure

Sandra Trudgen Dawson

History on British television: constructing nation, nationality and collective memory Robert Dillon

The food companions: cinema and consumption in wartime Britain, 1939-45 Richard Farmer

Songs of protest, songs of love: popular ballads in eighteenth-century Britain Robin Ganev

Heroes and happy endings: class, gender, and nation in popular film and fiction in interwar Britain Christine Grandy

Women drinking out in Britain since the early twentieth century David W. Gutzke

The BBC and national identity in Britain, 1922-53

Thomas Hajkowski

From silent screen to multi-screen: a history of cinema exhibition in Britain since 1896 Stuart Hanson

Juke box Britain: Americanisation and youth culture, 1945-60 Adrian Horn

Popular culture in London, c. I890-1918: the transformation of entertainment Andrew Horrall

Inventing the cave man: from Darwin to the Flintstones Andrew Horrall

Popular culture and working-class taste in Britain, 1930-39: a round of cheap diversions? Robert James

The experience of suburban modernity: how private transport changed interwar London John M. Law

Amateur film: meaning and practice, 1927-1977

Heather Norris Nicholson

Films and British national identity: from Dickens to Dad's Army Jeffrey Richards

Cinema and radio in Britain and America, 1920-60 Jeffrey Richards

Looking North: Northern England and the national imagination Dave Russell

The British seaside holiday: holidays and resorts in the twentieth century John K. Walton

Politics, performance and popular culture in the nineteenth century Peter Yeandle, Katherine Newe and Jeffrey Richards 


\section{Picturing home}

Domestic life and modernity in 1940s British film

\section{HOLLIE PRICE}

Manchester University Press 
Copyright $\odot$ Hollie Price 2021

The right of Hollie Price to be identified as the author of this work has been asserted by her in accordance with the Copyright, Designs and Patents Act 1988.

Published by Manchester University Press

Altrincham Street, Manchester M1 7JA

www.manchesteruniversitypress.co.uk

British Library Cataloguing-in-Publication Data

A catalogue record for this book is available from the British Library

ISBN 9781526138200 hardback

First published 2021

The publisher has no responsibility for the persistence or accuracy of URLs for any external or third-party internet websites referred to in this book, and does not guarantee that any content on such websites is, or will remain, accurate or appropriate.

Front cover - This Happy Breed, David Lean 1944, ITV/Shutterstock

Typeset by

Servis Filmsetting Ltd, Stockport, Cheshire 


\section{STUDIES IN \\ POPULAR \\ CULTURE}

There has in recent years been an explosion of interest in culture and cultural studies. The impetus has come from two directions and out of two different traditions. On the one hand, cultural history has grown out of social history to become a distinct and identifiable school of historical investigation. On the other hand, cultural studies has grown out of English literature and has concerned itself to a large extent with contemporary issues. Nevertheless, there is a shared project, its aim, to elucidate the meanings and values implicit and explicit in the art, literature, learning, institutions and everyday behaviour within a given society. Both the cultural historian and the cultural studies scholar seek to explore the ways in which a culture is imagined, represented and received, how it interacts with social processes, how it contributes to individual and collective identities and world views, to stability and change, to social, political and economic activities and programmes. This series aims to provide an arena for the cross-fertilisation of the discipline, so that the work of the cultural historian can take advantage of the most useful and illuminating of the theoretical developments and the cultural studies scholars can extend the purely historical underpinnings of their investigations. The ultimate objective of the series is to provide a range of books which will explain in a readable and accessible way where we are now socially and culturally and how we got to where we are. This should enable people to be better informed, promote an interdisciplinary approach to cultural issues and encourage deeper thought about the issues, attitudes and institutions of popular culture.

Jeffrey Richards 